\title{
КОНЦЕПТУАЛЬНА МОДЕЛЬ ВИКОРИСТАННЯ МКФ-ДП В ІНКЛЮЗИВНОМУ НАВЧАЛЬНОМУ ПРОЦЕСІ
}

Еляна Данілавічютє, Інститут спеціальної педагогіки і психології імені Миколи Ярмаченка Національної академії педагогічних наук України, м. Київ, Україна, elyana_d@ukr.net

Представлено сучасні уявлення про створення умов для комфортного функціонування дитини з ООП у дитячому колективі. Розкрито провідну роль пристосувального освітнього середовища у контексті перебігу означеного процесу, що підтверджує необхідність здійснення його ретельного аналізу з метою оцінки якості життєдіяльності дитини $з$ 00П й визначення заходів для подальшого вдосконалення умов її розвитку. Репрезентовано структуру Міжнародної класифікації функціонування, обмеження життєдіяльності, здоров'я дітей та підлітків (МКФ-ДП) як сучасного інструменту, що дає змогу скласти об'єктивне уявлення про стан дитини на основі обліку характеристик її розвитку та впливу на неї навколишнього середовища; концептуальну модель використання МКФ-ДП в інклюзивному навчальному процесі; алгоритм створення «пристосувань» з опорою на аналіз особливих освітніх потреб; типологію особливих освітніх потреб і їхню ієрархічну структуру, що виступає у якості основи подальшої педагогічної підтримки дітей з урахуванням необхідних «пристосувань».

Ключові слова: пристосувальне освітнє середовище, концептуальна модель МКФ, інклюзивний навчальний процес, типологія особливих освітніх потреб.

Эляна Данилавичюте, Институт специальной педагогики и психологии имени Николая Ярмаченко Национальной академии педагогических наук Украины, г. Киев, Украина.

Концептуальная модель использования МКФ-ДП в инклюзивном учебном процессе

Рассмотрены современные представления о создании условий для комфортного функционирования ребенка с 0ОП в детском коллективе. Раскрыта ведущая роль приспособительной образовательной среды в контексте протекания упомянутого процесса, что подтверждает необходимость осуществления его детального анализа с целью оценки качества жизнедеятельности ребенка с ООП и определения мероприятий для дальнейшего усовершенствования условий его развития. Представлена структура Международной классификации функционирования, ограничения жизнедеятельности, здоровья детей и подростков (МКФ-ДП) как современного инструмента, который дает возможность получить объективное представление о состоянии ребенка на основе учета характеристик его развития и воздействия на него окружающей среды; концептуальная модель использования МКФ-ДП в инклюзивном учебном процессе; алгоритм создания «приспособлений» с опорой (ㄱ Данілавічютє Е., 2018 
на анализ особых образовательных потребностей; типология особых образовательных потребностей, их иерархическая структура, что выступает в качестве основы дальнейшей педагогической поддержки детей с учетом необходимых «приспособлений».

Ключевые слова: приспособительная образовательная среда, концептуальная модель МКФ, инклюзивный учебный процесс, типология особых образовательных потребностей.

Elyana Danilavichiutie, Mykola Yarmachenko Institute of Special Pedagogy and Psychology of the National Academy of Educational Sciences of Ukraine, Kyiv, Ukraine

The conceptual model of ICF-CY usage in the inclusive educational process

A contemporary view of conditions creation for the comfortable functioning of a child with special educational needs (SEN) in the children's collective has been revealed in this article. A key role of an adaptive educational environment in the context of the mentioned process progress has been represented that proves the necessity of a detailed analysis for the purpose of the assessment of the quality of child's with SEN life-sustaining activity and procedures determination for hislher further development conditions improvement. The structure of the International Classification of Functioning, Disability, and Health: Children and Youth Version (ICF-CY) has been overviewed as a contemporary tool that gives a possibility to receive the objective visualization of the child's condition on the basis of taking into account the characteristics of hisher development and environmental influence. The conceptual model of ICF-CY usage in the inclusive educational process and the algorithm of "adaptations" creation, which is based on the analysis of SEN, have been represented in this article. The developed typology of SEN, its hierarchy structure has been described and the sample of its implementation has been demonstrated that proved the practicability of its usage as a foundation for the further pedagogical support of children with SEN taking into account necessary "adaptations". Keywords: an adaptive educational environment, the conceptual model of ICF-CY, the inclusive educational process, the typology of SEN.

3 адоволення особливих освітніх потреб дітей у контексті інклюзивної освіти спирається на середовищний niдxid (educational environment approach), який забезпечує гнучкість фізичного, психологічного і соціального середовища $[1 ; 2 ; 4 ; 5]$. Організація такого середовища передбачає створення умов для комфортного функціонування дитини з особливими освітніми потребами (ООП) у дитячому колективі. У якості загальних умов виступають:

- архітектурна доступність;

- сприятлива психоемоційна атмосфера;

- методичне забезпечення освітнього процесу відповідно до освітніх потреб конкретної дитини;

- співпраця усіх учасників інклюзивної освіти стосовно конкретної дитини;

- здійснення необхідних модифікацій середовища для конкретної дитини;

- постійне підвищення кваліфікації педагогів та різнопрофільних фахівців для удосконалення інклюзивного навчання;

- готовність дитини з ООП долучитися до функціонування у дитячому колективі. 


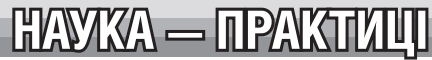

Ефективність створення таких умов, своєю чергою, залежить від правильності розуміння і врахування особливих освітніх потреб дитини [7]. Так, на перший план виступає не медичний діагноз, не своєрідність розвитку особистосmi або специфіка взаємодї із соціумом, а вплив пристосувального освітнього середовища з метою уможливлення або поліпшення функціонування дитини у процесі навчання у загальноосвітньому закладі.

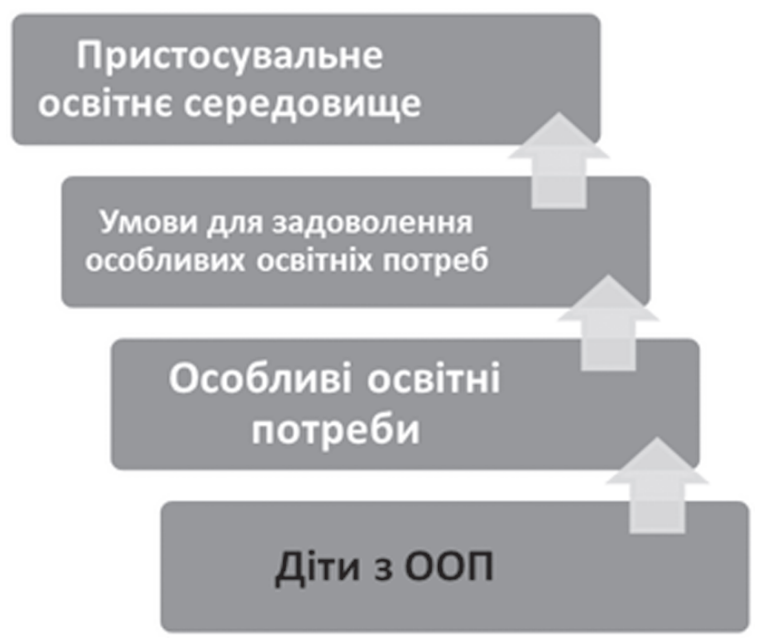

Водночас, упродовж життя будь-якої дитини постійно відбуваються зміни в середовищі, що її оточує. пов'язані зі зростанням iĭ компетенції у різних сферах життєдіяльності, ступенем участі у суспільному житті, самостійності й незалежності, а також появою керованих або «стихійних» пристосувань навколишнього середовища до особливих потреб у разі їхньої присутності. Це свідчить про необхідність здійснення аналізу і самого середовища, у якому зростає дитина. Такий аналіз дає змогу оцінити якість життєдіяльності й визначити заходи для подальшого вдосконалення дитячого середовища.

у якості сучасного інструмента, що дає змогу скласти об'єктивне уявлення на основі обліку характеристик розвитку дитини та впливу на неї навколишнього середовища, у багатьох країнах світу використовується Міжнародна класифікація функціонування, обмеження життєдіяльності, здоров'я дітей та підлітків (МКФ-ДП), яка походить від Міжнародної класифікації функціонування, обмеження життєдіяльності та здоров'я (МКФ) (B003, 2001)

МКФ-ДП розроблено відповідно до рекомендацій міжнародних конвенцій і декларацій, які проголошують права дітей. Основоположний документ, що було створено з акцентом на дітях і підлітках, які мають обмеження життєдіяльності, Конвенція ООН 1989 p. про права дитини. Стаття 23 цього документа наголошує на тому, що неповноцінна в розумовому або фізичному відношенні дитина має вести повноцінне $і$ гідне життя в умовах, які забезпечують ї гідність, сприяють почуттю впевненості в собі $і$ забезпечують ї активну участь у житті 
суспільства. Уже перший варіант МКФ було прийнято як одну з соціальних класифікацій Організації Об'єднаних Націй, де вона згадується та об'єднується в Стандартні правила щодо рівноправності можливостей для людей з обмеженнями життєдіяльності, що повністю відповідає соціальній моделі світогляду.

Інтерес до класифікації і іï позитивна оцінка підтверджуються тим, що іï схвалено всіма 191 членами Всесвітньої організації охорони здоров’я 22 травня 2001 року під час 54-ї Всесвітньої асамблеї охорони здоров’я.

27 грудня 2017 року Уряд України затвердив план заходів з впровадження МКФ та МКФ-

ДП в Україні, що є першим і дуже важливим кроком на шляху до реформи реабілітації та системи оцінювання фуункціонування

Інтеграція фізичних, психічних та соціальних показників, що характеризують стан дитини завдяки введеним до МКФ-ДП аспектам життєдіяльності (розвиток, участь та середовище), дає змогу зосередити увагу не на діагнозі, а на функиіональних можливостях організму дитини.

МКФ-ДП є класифікацією «компонентів здоров'я», а не «наслідків захворювання». у

ній відображено нейтральну позицію щодо етіології порушень стану здоров'я. Основу

класифікації складає демографічний підхід до запобігання обмеження життєдіяльності, тому 3

$\{$ їі допомогою можуть бути описані показники здоров'я; показники, що пов'язані зі здоров'ям;

стани здоров'я. Тому , МКФ-ДП $є$ універсальним інструментом 3 точки зору її застосування

як для профрілактики виникнення обмежень функціонування, так і для створення стратегії

їхнього усунення. Це означає, що МКФ-ДП може використовуватися для всіх без винятку

$\{$ дітей $\boldsymbol{i}$ підлітків віком до 18 років, виступаючи підгрунтям для організації, зокрема, і

раннього втручання, що є надзвичайно актуальним для нашої країни

Використання МКФ-ДП розкриває широкі перспективи для подальшого впровадження міждисииплінарного підходу в систему надання допомоги дітям 3 ООП у процесі професійної взаємодії різнопрофільних фахівців. Цінним є той факт, що у контексті застосування МКФ-ДП і освітяни, і лікарі, і соціальні працівники стають ініціаторами поліпшення умов життєдіяльності дитини. Командний nidxid (team approach) [6] набуває ще більшого значення у контексті інклюзивної освіти з використанням показників МКІ-ДП: відбувається чіткіша диференціація послуг кожного фахівця, а, водночас, набувають конкретики завдання, які потребують участі всіх учасників команди.

Важливо звернути увагу на те, що класифікація охоплює широкий контекст здоров'я та залишає поза увагою обставини, які не пов'язані зі здоров'ям. До останніх відносяться ті, що є наслідком упливу соціально-економічних чинників. Наприклад, діти і підлітки можуть бути обмеженими при виконанні завдань у їхньому поточному середовищі через їхню расу/національність, гендер, релігію або інші соціально-економічні характеристики, але це не пов'язано із обмеженням здоров'я та участі, на чому наголошується у МКФ. Означені причини обмежень функціонування потребують розгляду з позицій соціоадаптаційного nidxoдy. Тому, у якості індикаторів таких обмежень у цих випадках виступають 


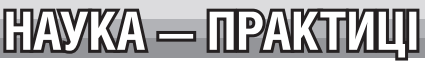

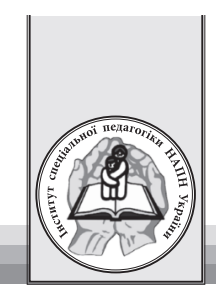

показники ступеня соціальної адаптащії (дезадаптаціі). Відповідно до класифікаційних ознак (див. статтю Е. Данілавічютє «Діти з особливими освітніми потребами в інклюзивному середовищі» у попередньому випуску журналу [3]), ці обмеження життєдіяльності потрапляють до групи особливостей розвитку внаслідок впливу соиіального середовища. За ознакою наявності обмежень функціонування вони також потребують створення пристосувального освітнього середовища у контексті інклюзії, проте не можуть бути піддані аналізу через МКФ-ДП.

Концептуальна модель використання МКФ-ДП для створення пристосувального середовища у контексті інклюзивного навчання

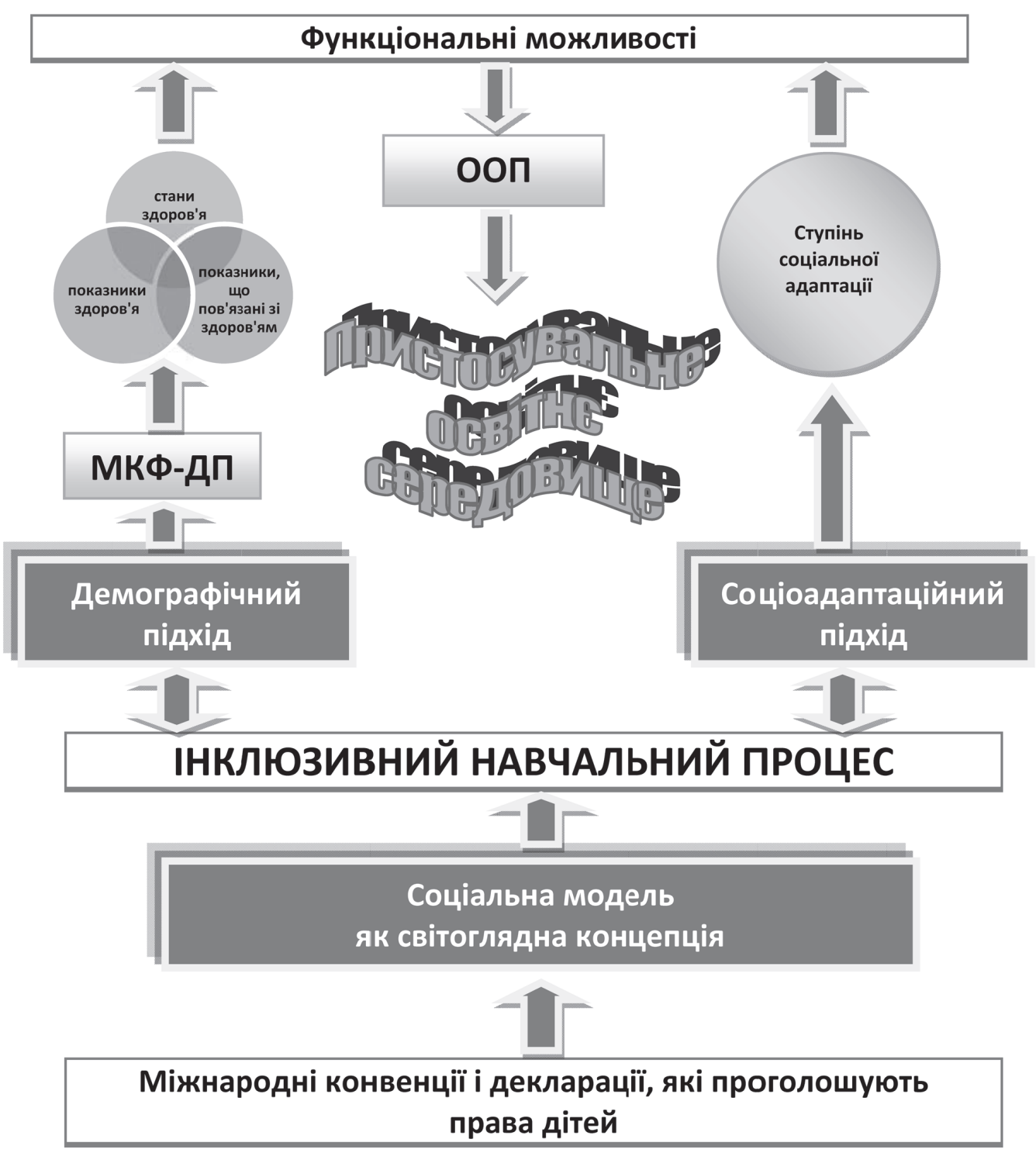


Практичне застосування МКФ-ДП в умовах інклюзії слугує для деталізації особливостей функціонування дитини та опису ї обмежень, а також для зручної організації цієї інформації (див. нижче структуру МКФ-ДП, що представлена як складова організації інклюзивного навчання). Відповідно до потреби визначення показників здоров'я, а також показників, що пов'язані зі здоров'ям і станів здоров'я, на чому було наголошено вище, усі відомості класифікації розташовано в двох частинах: частина 1 - функціонування та обмеження життедіяльності (компоненти: «Організм», «Активність та Уиасть»), частина 2 контекстуальні фактори (компоненти: «Фактори навколишнього середовища», «Особистісні фактори»). Кожен з компонентів, що складають зміст обох частин у структурі МКФ-ДП, містить домени:

- функції і структури організму (фізіологічні функції систем організму, зокрема психологічні функції; анатомічні частини організму, такі як органи, кінцівки та їхні компоненти) - компонент «Організм»;

- життєві сфери (навчання та застосування знань, загальні завдання та вимоги, комунікація, мобільність, самообслуговування, участь у повсякденному житті, міжособистісні стосунки, основні сфери життя, соціальне та суспільне життя) - компонент «Активність та Уиасть»;

- зовнішній вплив на функціонування та обмеження життєдіяльності (фізичне, соціальне середовище та середовище відносин і установок, у яких діти/ підлітки живуть і проводять своє життя) - компонент «Фактори навколишнього середовища»;

- внутрішній вплив на функціонування та обмеження життєдіяльності (особливості індивіда, які не є частиною стану здоров'я або станів, пов'язаних зі здоров'ям: стать, вік, спосіб життя, звички, виховання і тощо) - компонент «Особистісні фактори».

Для оцінки можливостей функціонування структура класифікації передбачає кваліфікатори, які дають змогу визначити код якості функціонування, поданий у додатку, для кожного з доменів. Це означає, що вся зібрана у контексті певного домену інформація співвідноситься з відповідним кодом (кодується за допомогою певних цифр і літер). У результаті з'являється набір кодів з переліком результатів аналізу кожного домену, який має назву конструкиї. Для кожного домену існують свої кваліфікатори:

- домен функції $і$ структури організму: зміна у функції організму (фізіологічна); зміна у структурі організму (анатомічна), який конкретизується у вигляді втрати чи відсутності, редукції; додавання або надлишку, відхилень з визначенням ступеня тяжкості, часу виникнення, особливостей перебігу, первинності й вторинності виникнення у структурі цілісного порушення;

- домен життєві сфери: реалізація (опис того, що дитина робить у поточному середовищі), здатності (опис здатності дитини виконувати завдання або дію);

- домен зовнішні впливи на функціонування та обмеження життедіяльності: виявлення бар'єрів (перешкод) (наприклад, недоступні будинки) або полегшуючого фактору (наприклад, ступінь доступності допоміжних пристроїв); 


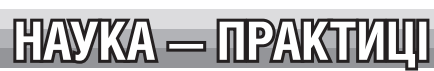

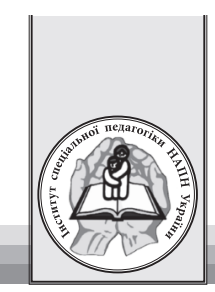

- домен внутрішні впливи на функціонування та обмеження життєдіяльносmi: відсутні кваліфікатори за причини індивідуального прояву, але вони враховуються.

\section{Структура МКФ-ДП як складова організації інклюзивного навчання}

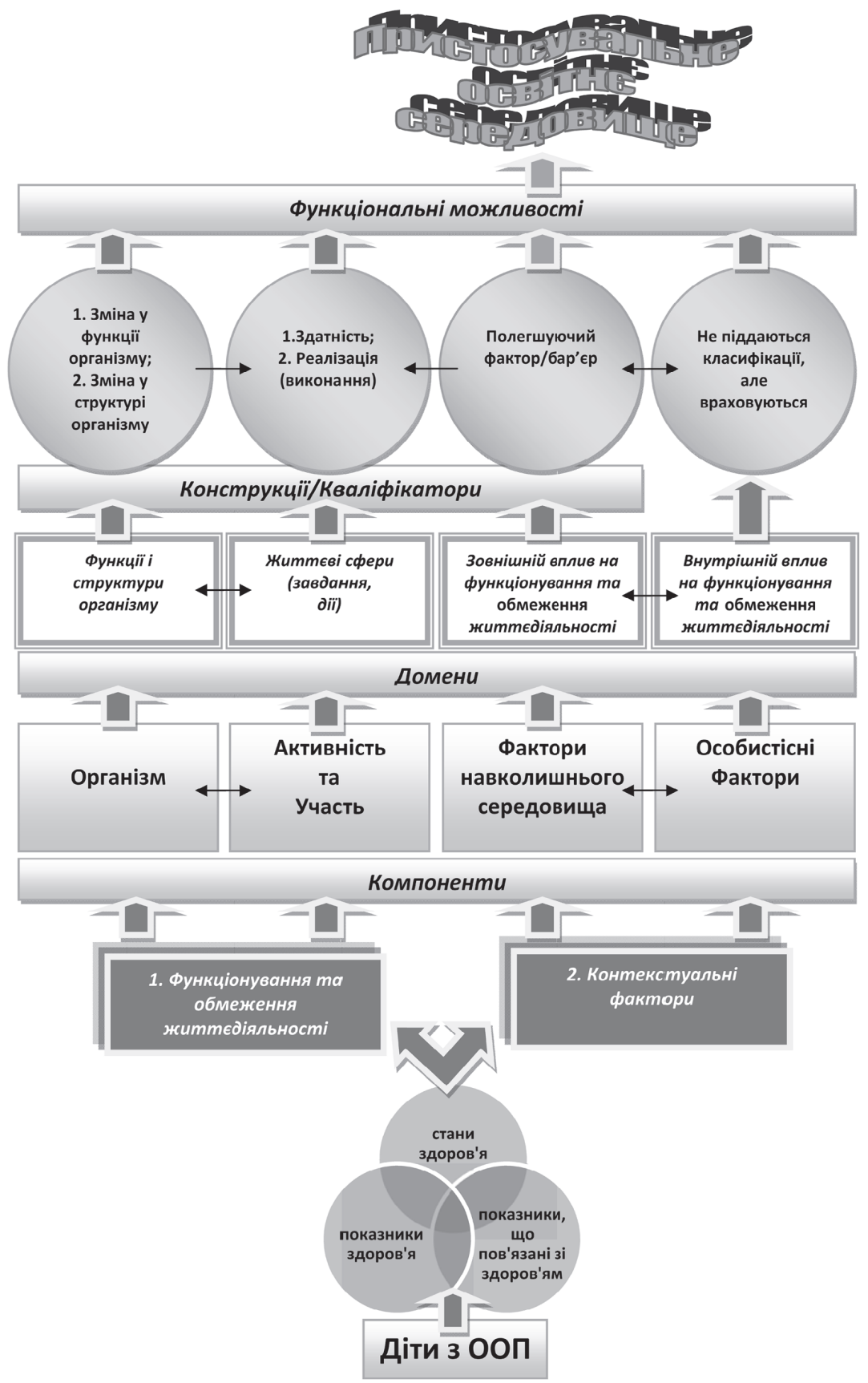


Для правильної організації пристосувального освітнього середовища особливої актуальності набуває визначення індивідуальних факторів (фізичної та матеріальної специфіки середовища, своєрідності безпосереднього контакту з людьми: родиною, знайомими, однолітками та незнайомими) і сощіальних факторів (організацій та послуг, що пов'язані з робочим середовищем, діяльністю громад, державними установами, комунікацією і транспортними послугами та неформальними соціальними мережами, а також законами, нормативними актами, формальними та неформальними правилами, ставленнями та ідеологіями) навколишнього середовища. Вони можуть виступати у ролі таких, що полегшують навчання дитини з ООП, а також таких, що виступають у якості перешкод на шляху до опанування знань у навчальному закладі.

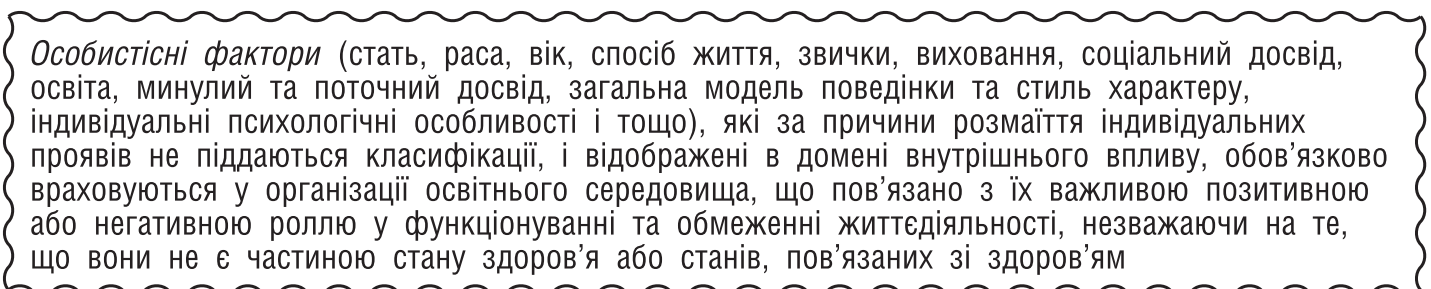

Типологія ООП як основа педагогічної підтримки дітей в освітньо-розвивальному середовищі

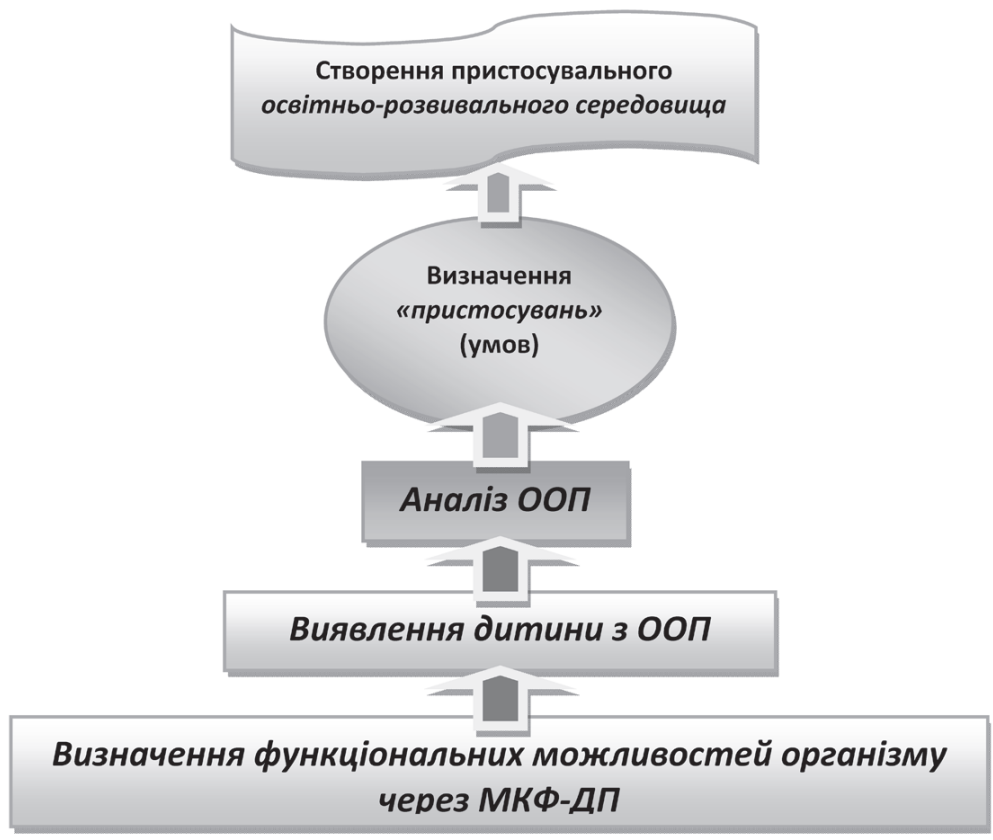

Оцінювання функціональних можливостей організму дитини за допомогою МКФ-ДП дає змогу визначити їі особливі освітні потреби. Саме вони виступають 


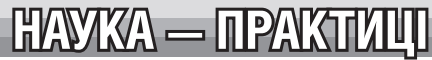

у якості підгрунтя організації пристосувального освітньо-розвивального середовища. Воно має на меті створення всіх необхідних умов для комфортного перебування дитини у навчальному закладі, їі участі у навчально-виховному процесі та соціальної адаптаціі. У такому контексті акцент переноситься з особи на «nристосування», які сприятимуть доланню бар'єрів залучення дитини в загальноосвітній простір. Ключ для створення «пристосувань»- аналіз особливих освітніх потреб, якому належить провідне місце у поданому нижче алгоритмі.

Відповідно до класифікаційних ознак ООП і категорій дітей з ООП, всі особливі освітні потреби можна розподілити на декілька типів:

- інтелектуальні, які можуть полягати в обмеженні функціонування різного ступеня прояву передумов інтелекту (пам'яті, уваги, мислення, мовлення, вольових процесів, мотивації тощо), власне інтелекту (здатності до узагальнення, абстрагування, міркування; продукування думки, судження; здатності робити висновки тощо), інвентарю інтелекту (умінь, знань, набутих навичок);

- функціональні (сенсорні, моторні), які можуть полягати в обмеженні життєдіяльності різного ступеня прояву слухової, зорової, опорно-рухової (кістковом'язової), мовленнєвої функцій;

- фізичні, які можуть полягати в обмеженні функціонування різного ступеня прояву органів та кінцівок дитячого організму;

- навчальні, які можуть полягати в обмеженні або своєрідності перебігу довільних видів діяльності різного ступеня прояву (писемного виду діяльності, математичних дій і тощо);

- соціоадаптапційні (особистісні, середовищні), які можуть полягати в індивідуальних відмінностях різного ступеня прояву (див. параграф 3.3 цього розділу) або дезадаптації як відповіді організму на зміни у соціальному навколишньому середовищі.

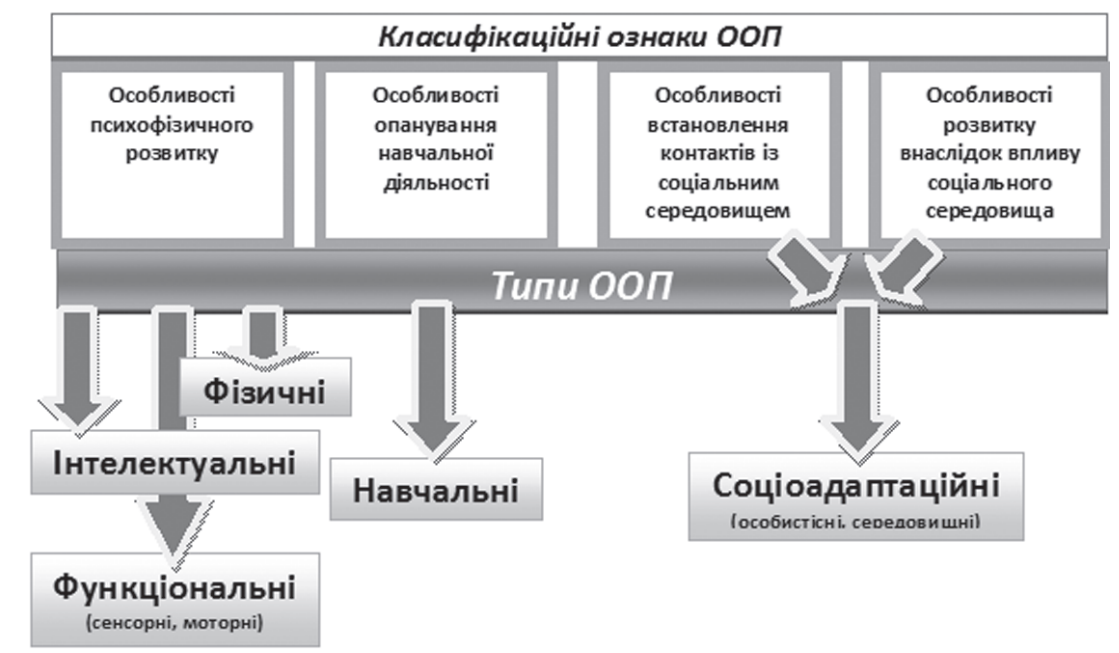

«ОСОБЛИВА ДИТИНА: навчання і виховання», № 4, 2018 
Надзвичайно важливим для організації навчання є той факт, що типологія ООП має свою ієрархіину структуру, підгрунтя якої - біо-психо-соціальна модель розвитку становлення дитячого організму. Інтелектуальні, функиіональні (сенсорні, моторні) $i$ фізичні особливі потреби - ієрархічно нижчий рівень, який демонструє психофізіологічні можливості організму. Навчальні особливі потреби - ієрархічно вищий рівень, який базується на попередньому і демонструє здатність до опанування довільних видів діяльності. Соціоадаптаційні особливі потреби (особистісні, середовищні) - ієрархічно найвищий рівень, який відображає якість взаємодії дитини і поточного середовища.

Розуміння ієрархії потреб дає змогу чітко визначити послідовність виникнення причин обмеження життєдіяльності, а значить бар'єрів на шляху до опанування знань. Це, своєю чергою, дає змогу правильно обрати стратегію педагогічного впливу, уникаючи зайвих кроків

Наприклад, якщо дитина не має психофізіологічних обмежень, однак характеризується наявністю навчальних особливих потреб, педагогічна підтримка буде стосуватися саме їх задоволення. Водночас, у такої дитини можуть бути обмеження взаємодії із поточним соціальним середовищем, що свідчить про існування соиіоадаптаційних особливих потреб, які в такому випадку мають вторинний характер і також вимагають застосування відповідних педагогічних стратегій у правильній послідовності.

\section{Ієрархічна структура ООП}

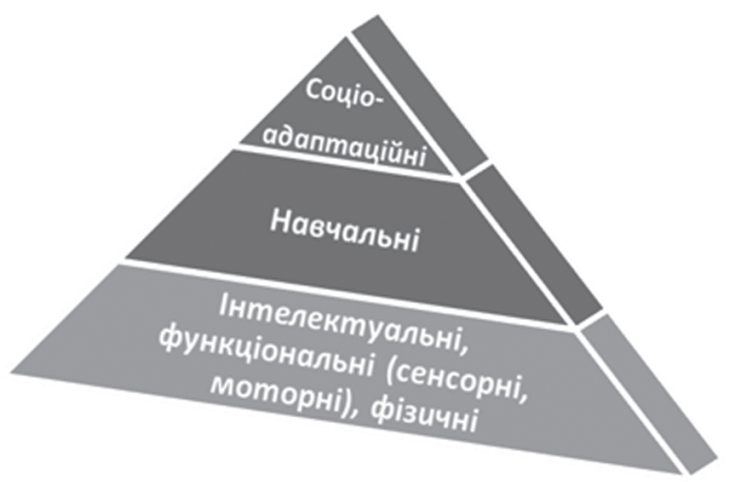

Виявлення потреб, їх аналіз і встановлення ієрархії дають змогу звернутися до загального алгоритму педагогічної підтримки дітей з урахуванням необхідних «пристосувань»:

- визначення й погодження аспектів навчання, що потребують застосування спеціальних методик, певної адаптащї завдань, модифікацій класного середо- 
вища, створення особливого графіка навчального навантаження відповідно до типу ООП; визначення довгострокової цілі та короткострокових завдань, критеріїв оцінювання, планів роботи для кожного попередньо погодженого аспекту; визначення й погодження необхідних супровідних послуг (зокрема інтегрованих із залученням фахівців спеціальних навчальних закладів, реабілітаційних центрів, установ медичного профілю тощо); призначення та погодження дати наступної зустрічі (обов'язкові наступні зустрічі з попереднім оцінюванням: кінець першого семестру, кінець навчального року, а також можливі проміжні за необхідності);

- визначення можливостей навчального закладу щодо організації необхідних супровідних послуг з адаптації внутрішнього та зовнішнього середовища (архітектура, обладнання, транспортування тощо); забезпечення навчально-методичними та технічними матеріалами; проведення розвивальних i додаткових занять (учителем-логопедом, психологом, іншими фахівцями та за підтримки батьків) за рахунок ресурсів закладу; здійснення обміну досвідом членами команди фахівців;

- визначення необхідності залучення зовнішніх ресурсів та фахівців з метою забезпечення супровідних послуг (таких, що вимагають, наприклад, використання спеціальної апаратури, обладнання тощо); організація співпраці (навчального закладу з іншими інституціями): звернення до органів управління освітою, ресурсних консультативних служб щодо сприяння співпраці із спеціальними навчальними закладами певного профілю - для дітей 3 порушеннями зору, слуху тощо; навчально-реабілітаційними центрами, медичними установами, які можуть забезпечити необхідні супровідні послуги; укладання угод з відповідними закладами (формування об'єднань навчальних закладів, що підтримують інклюзію, та спеціальних, які активно співпрацюють, використовуючи персонал та ресурси, спільно проводячи заходи тощо);

- визначення шляхів узгодження супровідних послуг (розвивальних, додаткових занять) та загального навчально-виховного процесу (зміни у розкладі, навчальному плані, визначення місця проведення: на базі основного закладу, в умовах інших інституцій);

- здійснення моніторингу шляхом самооцінювання (рефлексіі) ступеня зростання показників задоволення особливих освітніх потреб у навчальному закладі (стосується усіх учасників навчально-виховного процесу та батьків).

Загальний алгоритм педагогічної підтримки містить усі можливі варіанти врахування ООП і є гнучким: його компоненти використовуються відповідно до необхідності «пристосувань» для конкретної дитини, передбачаючи всі варіанти сполучуваності.

Отже, педагогічна підтримка дітей з ООП в освітньо-розвивальному середовищі передбачає чітке визначення типу/типів потреб, виявлення ієрархії їх виникнення, очінювання можливостей навчального закладу стосовно «пристосувань» до потреб дитини (облаштування фізичного середовища, застосування матеріалів, ресурсів і технологій навчання або способів їх пристосування до потреб дитини), залучення зовнішнъої підтримки у разі необхідності, а також безпосередню організачію інклюзивного навчального прощесу.

«ОСОБЛИВА ДИТИНА: навчання і виховання», № 4, 2018 


\section{ЛITEPATУPA}

1. Данілавічютє E. А., Литовченко C. В. Стратегії викладання в інклюзивному навчальному закладі: навчально-методичний посібник / За ред. А. А. Колупаєвої. - К.: Видавнича група «A.C.K.», 2012. - 350 c.

2. Данілавічюте E. А. Закономірності виникнення, сутність та місце інклюзії у єдиній системі освіти в Україні. / Е. А. Данілавічютє // Особлива дитина: навчання та виховання. 2013. - № 1. - C. 2-8.

3. Данілавічютє E. А. Діти з особливими освітніми потребами в інклюзивному середовищі. / Е. А. Данілавічютє // Особлива дитина: навчання та виховання. - 2018. - № 3. - С. 7-19.

4. Колупаєва A. A. Від сегрегації до інклюзії // Дидактичні та соціально-психологічні аспекти корекційної роботи у спеціальній школі: Наук.- метод. зб. Випуск 6. - К.: Науковий світ, 2005. - С. 52-56.

5. Основи інклюзивної освіти. Навчально-методичний посібник / за заг. ред. А. А. Колупаєвої - К: «А. С. К. , 2012. - 308 с.

6. Програмно-методичний комплект «Професійне співробітництво в інклюзивному навчальному закладі»: Колупаєва А. А., Данілавічюте Е. А., Литовченко С. В. Професійне співробітництво в інклюзивному навчальному закладі: навчально-методичний посібник. - К.: Видавнича група «А.С.К.», 2012. - 197 с. - (Серія «Інклюзивна освіта»)

7. Kolupayeva A., Taranchenko O., Danilavichute E. (2014), Special Education Today in Ukraine, in Anthony F. Rotatori, Jeffrey P. Bakken, Sandra Burkhardt, Festus E. Obiakor, Umesh Sharma (ed.) Special Education International Perspectives: Practices Across the Globe (Advances in Special Education, Volume 28) Emerald Group Publishing Limited, pp. 311-351.

\section{REFERENCES (TRANSLATED AND TRANSLITERATED)}

1. Danilavichiutie E. A., Lytovchenko S.V. Strategiji vykladannia v inkliuzyvnomu navchalnomu zakladi: navchalno-metodychnyj posibnyk / Za red. A.A. Kolupajevoji. - K.: Vydavnycha grupa «A.S.K.», 2012. - 350 p.

2. Danilavichiutie E. A. Zakonomirnosti vynyknennia, sutnist ta mistse inkliuziji u jedynij systemi osvity v Ukrajini. / E. A. Danilavichiutie // Osoblyva dytyna: navchannia ta vyhovannia. 2013. - № 1. - S. 2-8.

3. Danilavichiutie E.A. Dity z osoblyvymy osvitnimy potrebamy v inkliuzyvnomu seredovyshchi. / E. A. Danilavichiutie // Osoblyva dytyna: navchannia ta vyhovannia. - 2018. - № 3 . - C. 7-19.

4. Kolupaieva A. A. Vid sehrehatsiji do inkliuziji // Dydaktychni ta sotsialno-psyholohichni aspekty korektsijnoji roboty u spetsialnij shkoli: Nauk.- metod. zb. Vypusk 6. - K.: Naukovyj svit, 2005. - S. 52-56.

5. Osnovy inkliuzyvnoji osvity. Navchalno-metodychnyj posibnyk / za zah. red. Kolupaieva A. A. - K: «A. S. K. », 2012. - 308 s.

6. Prohramno-metodychnyj komplekt «Profesijne spivrobitnytstvo v inkliuzyvnomu navchalnomu zakladi»: Kolupaieva A.A., Danilavichiutie E.A., Lytovchenko S.V. Profesijne spivrobitnytstvo v inkliuzyvnomu navchalnomu zakladi: navchalno-metodychnyj posibnyk. - K.: Vydavnycha grupa «A.S.K.», 2012. - 197 c. - (Serija «Inkliuzyvna osvita»)

8. Kolupayeva A., Taranchenko O., Danilavichute E. (2014), Special Education Today in Ukraine, in Anthony F. Rotatori, Jeffrey P. Bakken, Sandra Burkhardt, Festus E. Obiakor, Umesh Sharma (ed.) Special Education International Perspectives: Practices Across the Globe (Advances in Special Education, Volume 28) Emerald Group Publishing Limited, pp. 311 - 35. 